\title{
PENERAPAN MANAJEMEN KREDIT PADA PROGRAM KEMITRAAN DAN BINA LINGKUNGAN (PKBL) PT PELINDO II CABANG PALEMBANG MELALUI KARAKTER, KONDISI USAHA, JAMINAN DAN PENYEBAB LAINNYA
}

\author{
Meilin Veronica \\ Program Studi Manajemen, Universitas Indo Global Mandiri \\ Email: meilinveronica@uigm.ac.id
}

\begin{abstract}
Corporate Social Responsibility Program of PT PELINDO II Branch Palembang is a program to improve the ability of small businesses to become strong and independent through the use of funds from the profits of PT PELINDO II BranchPalembang. The purpose of this research was to determine the application of credit management in the corporate social responsibility program(PKBL) PT. PELINDO II (Persero) Branch Palembang through character, business conditions, guarantees and other causes. The research methodology used in this research was to distribute questionnaires to 34 fostered partners, 1 PKBL employee and 1 supervisor. The results of the study show that the character of the fostered partners is of the opinion that PT. PELINDO II branch Palembang will not suffer losses even if the credit received is not returned. Seen from the questionnaire sample where 30 fostered partners (88.2\%) strongly agree that if the PKBL credit loan is not returned, PT. PELINDO II branch Palembang has nothing to lose, so it has a big role in causing a large amount of arrears. Suggestions for further research are eliminating miscommunication with fostered partners, coordinating with other state-owned enterprises, conducting surveys of fostered partners, making effective visits to fostered partner locations and selection of prospective foster partners must be done correctly and transparently.
\end{abstract}

Keywords : Credit Management, Corporate Social Responsibility Program

\section{DASAR PEMIKIRAN}

Sejak krisis ekonomi yang dimulai pertengahan 1997, dampak sosial ekonomi sangat terasa di kalangan masyarakat.Apalagi saat kejadian Kerusuhan Mei 1998, banyak perusahaan tutup dan menimbulkan gelombang pengangguran yang hingga kiini masih terasa di tengah masyarakat. Namun, lambat laun pemerintah menyadari, bahwa melalui cara menyisihkan laba BUMN maka diharapkan dapat mengurangi kesulitan sosial dan ekonomi rakyat.

Badan Usaha Milik Negara (BUMN) menurut Undang-undang Nomor 19 Tahun 2003 adalah Badan Usaha Milik Negara, yang selanjutnya disebut BUMN, adalah badan usaha yang seluruh atau sebagian besar modalnya dimiliki oleh negara melalui penyertaan secara langsung yang berasal dari kekayaan negara yang dipisahkan. 
30 | Meilin Veronica Penerapan Manajemen Kredit Pada Program.....

Undang-undang No. 19 tentang Badan Usaha Milik Negara yang dibentuk dengan beberapa alasan yang menjadi pertimbangan, antara lain karena Badan Usaha Milik Negara mempunyai peranan penting dalam penyelenggaraan perekonomian nasional guna mewujudkan kesejahteraan masyarakat.

PKBL adalah Program Kemitraan dan Bina Lingkungan yang dahulu dikenal dengan nama Program Pembinaan Usaha Kecil \& Koperasi (Program PUKK) yang diharapkan dapat meringankan beban masyarakat. Makanya tidak heran, saat krisis melanda Indonesia, banyak "pengusaha mikro' dadakan.Program Kemitraan BUMN Dengan Usaha Kecil yangbiasa disebut Program Kemitraan adalah program untuk meningkatkan kemampuan usaha kecil dan mikro agar menjadi tangguh dan mandiri, sekaligus memberikan multiplier effect bagi peningkatan perekonomian dan kesejahteraan masyarakat. Program kemitraan dan bina lingkungan atau PKBL diatur dalam Keputusan menteri BUMN no.236/MBU/2003 tanggal 17 Juni 2003 tentang pedoman pelaksanaan program kemitraan badan usaha milik negara dengan usaha kecil dan program bina lingkungan dan Peraturan menteri BUMN nomor per-05/mbu/2007 program kemitraan badan usaha milik negara dengan usaha kecil dan program bina lingkungan.

PT. PELINDO II (Persero) Cabang Palembang merupakan pintu gerbang perekonomian dan pembangunan daerah Sumatera Selatan, sebagai Badan Usaha Milik Negara, PT. PELINDO II (Persero) dituntut untuk dapat menghasilkan profit dari kegiatan juga harus dapat memberikan kontribusi positif terhadap perkembangan suatu daerah, agar eksistensi tetap diakui masyarakat maka perusahaan harus peduli terhadap lingkungan sekitarnya. Sebagai tanggung jawab social perusahaan (Corporate Social Responsibility) salah satu wujud kepedulian perusahaan adalah Program Kemitraan dan Program Bina Lingkungan (PKBL).

Berikut adalah Tabel 1.1 tentang Data Piutang Pinjaman Dana PKBL Tahun 2015 s.d 2018 PT. PELINDO II (Persero) Cabang Palembang. 
Ekonomica Sharia Volume 5 Nomor 1 Edisi Agustus 2019 | 31

\begin{tabular}{|c|c|c|c|c|c|c|c|c|}
\hline \multirow[b]{2}{*}{ Tahun } & \multirow[b]{2}{*}{$\begin{array}{c}\text { Jumlah } \\
\text { mitra } \\
\text { binaan }\end{array}$} & \multirow[b]{2}{*}{$\begin{array}{c}\text { Jumlah } \\
\text { Mitra } \\
\text { binaan } \\
\text { yang } \\
\text { nunggak }\end{array}$} & \multicolumn{3}{|c|}{ PIUTANG } & \multicolumn{2}{|c|}{ Jumlah ansuran } & \multirow{2}{*}{$\begin{array}{l}\text { Total kredit yg } \\
\text { disalurkan } \\
\text { (Lancar+kuran } \\
\text { g lancar + } \\
\text { ragu-ragu + } \\
\text { macet+ } \\
\text { bermasalah) }\end{array}$} \\
\hline & & & $\begin{array}{c}\text { Lancar } \\
\text { (s/d } 30 \text { Hari) }\end{array}$ & $\begin{array}{c}\begin{array}{c}\text { Kurang } \\
\text { lancar }\end{array} \\
(31-180 \mathrm{hr})\end{array}$ & $\begin{array}{l}\text { Ragu-ragu } \\
\text { (181-270 hr) }\end{array}$ & $\begin{array}{c}\text { Macet } \\
\text { (lbh dr } 270 \\
\text { hr) }\end{array}$ & $\begin{array}{c}\text { Bermasala } \\
\mathrm{h}\end{array}$ & \\
\hline 2015 & 183 & 134 & 393.385 .822 & 60.068 .176 & 256.424 .624 & 877.588 .800 & $\begin{array}{c}216.625 .9 \\
88\end{array}$ & 1.804 .093 .411 \\
\hline 2016 & 182 & 132 & 521.090 .788 & 78.689 .059 & 198.781 .529 & 447.192 .722 & $\begin{array}{c}627.461 .0 \\
63\end{array}$ & 1.873 .215 .161 \\
\hline 2017 & 194 & 137 & 549.409 .785 & 117.569 .853 & 264.281 .168 & 480.775 .503 & $\begin{array}{c}627.461 .0 \\
63\end{array}$ & 2.039.497.372 \\
\hline 2018 & 176 & 130 & 178.227 .285 & 199.863 .356 & 230.872 .864 & 433.621 .139 & $\begin{array}{c}621.461 .0 \\
63\end{array}$ & 1.664 .045 .707 \\
\hline Total & & 533 & 1.642.113.680 & 456.190.444 & 950.361.185 & 2.239.178.164 & $\begin{array}{c}2.093 .009 \\
.177\end{array}$ & 7.380.851.651 \\
\hline
\end{tabular}

\section{Sumber : Laporan PKBL Cabang Palembang}

Berdasarkan Kebijakan dan Pedoman Program Kemitraan Bina Lingkungan PT. PELINDO II Cabang Palembang, penggolongan kualitas pinjaman terbagi atas:

1. Lancar adalah pembayaran angsuran pokok dan bunga tepat waktu.

2. Kurang lancar, apabila terjadi keterlambatan pembayaran angsuran pokok dan atau bunga yang telah melampaui 31 hari dan belum melampaui 180 hari dari tanggal jatuh tempo pembayaran angsuran sesuai dengan perjanjian yang telah disetujui bersama.

3. Diragukan, apabila terjadi keterlambatan pembayaran angsuran pokok dan atau bunga yang telah melampaui 181 hari dan belum melampaui 270 hari dari tanggal jatuh tempo pembayaran angsuran sesuai dengan perjanjian yang telah disetujui bersama.

4. Macet, apabila terjadi keterlambatan pembayaran angsuran pokok dan atau bunga yang telah melampaui 270 hari dari tanggal jatuh tempo pembayaran angsuran sesuai dengan perjanjian yang telah disetujui bersama. 
32 | Meilin Veronica Penerapan Manajemen Kredit Pada Program.....

Tabel 1.1 diatas menunjukkan masalah tunggakan yang jumlahnya sebesar Rp. 4.332.187.341.Dapat diketahui bahwa besarnya prosentase tunggakan adalah Rp. 4.332.187.341 / Rp. 7.380.851.651 x $100=59 \%$.Besarnya prosentase jumlah tunggakan yang macet mencapai angka 59\% dari penyaluran kredit tahun 2015 sampai 2018. Berdasarkan data tersebut dana sebesar 59\% tersebut akan mempengaruhi program dana bergulir dan kinerja dari PKBL PT. PELINDO II Cabang Palembang sehingga diperlukan suatu metode atau cara pengelolaan yang baik terhadap penyaluran kredit. Pengelolaan kredit yang baik berperan penting dalam menjaga kondisi likuiditas.

Berikut adalah Tabel 1.2 tentang Data Tingkat Pengembalian Pinjaman Dana PKBL Tahun 2015 s.d 2018 PT. PELINDO II (Persero) Cabang Palembang.

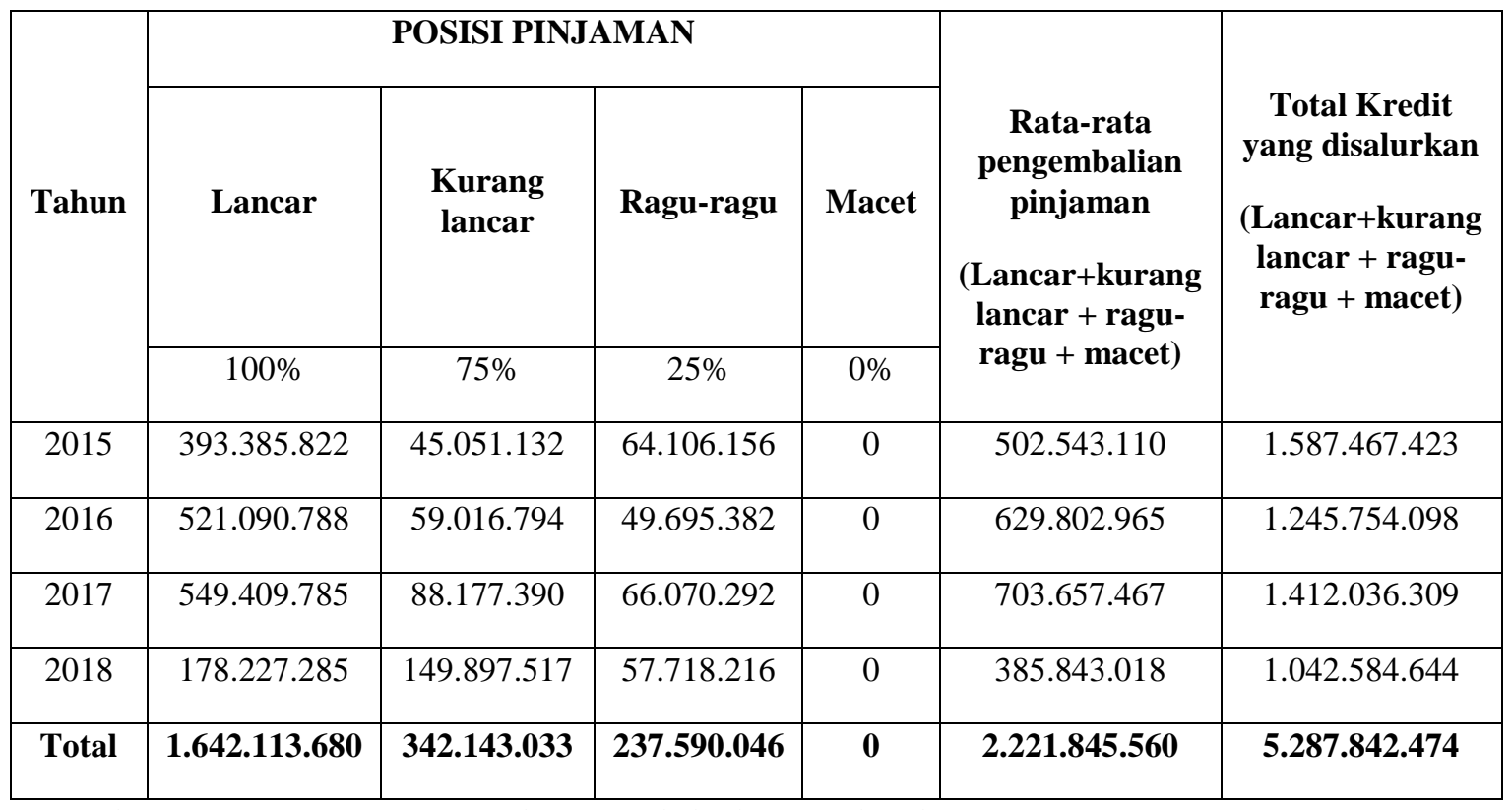

Sumber : Laporan PKBL Cabang Pelabuhan Palembang

Tabel $1.2 \mathrm{di}$ atas menunjukkan masalah tingkat pengembalian pinjaman dimana rata-rata tertimbang kolektibilitas pinjaman x 100\% / jumlah pinjaman yang disalurkan. Pada tahun 2015 tingkat pengembalian pinjaman sebesar 32\%, pada tahun 2016 mengalami peningkatan menjadi sebesar 51\%, pada tahun 2017 tingkat pengembalian pinjaman menurun menjadi 50\% dan pada tahun 2018 tingkat pengembalian pinjaman menurun menjadi $37 \%$ 
Ekonomica Sharia Volume 5 Nomor 1 Edisi Agustus 2019 |33

\section{KERANGKA PEMIKIRAN}

Berdasarkan uraian teoritik yang telah diterangkan di atas, dengan adanya penerapan manajemen kredit pada PKBL sehingga dapat disusun kerangka pemikiran yang digunakan dalam penelitian ini :

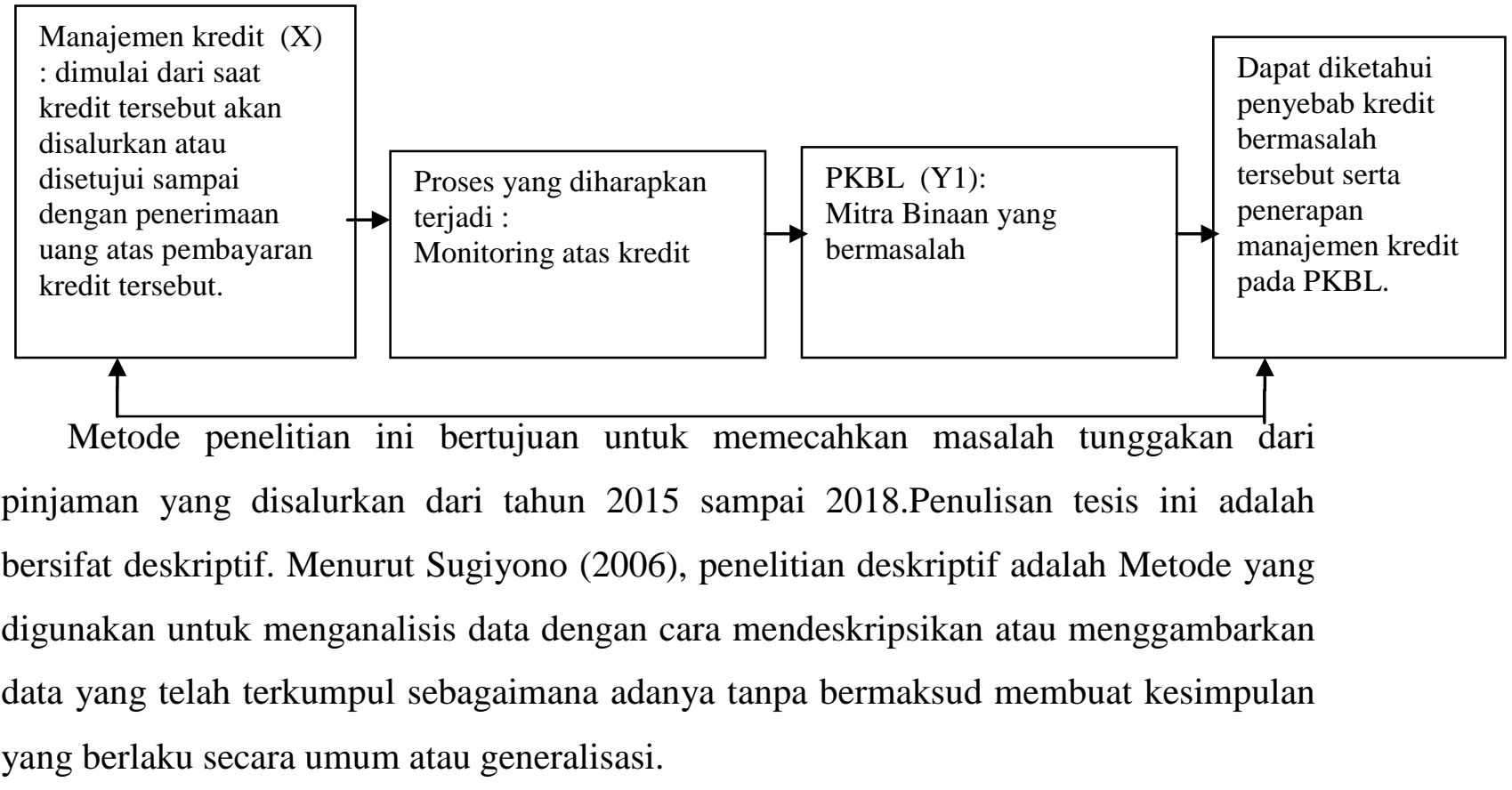

\section{METODOLOGI PENGUMPULAN DATA}

Metode pengumpulan data berupa :

1. Wawancara tidak terstruktur

Menurut Murti dan Salamah (2006), wawancara tidak terstruktur adalah wawancara yang bebas dimana peneliti tidak menggunakan pedoman wawancara yang telah tersusun secara sistematis dan lengkap untuk pengumpulan datanya.

2. Kuesioner (Angket)

Menurut Murti dan Salamah (2006), Kuesioner merupakan metode pengumpulan data yang paling efisien karena peneliti tidak perlu mendatangi responden, cukup menyiapkan daftar pertanyaan tertulis yang dikirim kepada responden untuk dijawab.Cara ini sesuai apabila jumlah responden cukup besar atau lokasi mereka tersebar di beberapa wilayah. 
34 | Meilin Veronica Penerapan Manajemen Kredit Pada Program.....

\section{METODE ANALISIS DATA}

Teknik analisa data yang digunakan untuk mengetahui penerapan manajemen kredit padaProgram Kemitraan dan Bina Lingkungan (PKBL) oleh PT.PELINDO II (Persero) Cabang Palembang adalah sebagai berikut :

a. Untuk data primer berupa penyebaran kuisioner yang dikirimkan kepada mitra binaan, hasilnya akan ditabulasi dan akan dianalisa menggunakan analisa data dengan Program SPSS. Pertanyaan- pertanyaan tersebut akan dikelompokkan menjadi 4 atau 5 kelompok penyebab/kelompok masalah kenapa mitra binaan tidak melunasi pinjamannya.

b. Untuk data sekunder yang berupa arsip-arsip, dokumen-dokumen, formulirformulir yang digunakan oleh Bagian PKBL untuk menyalurkan dana ke mitra binaan sejak proses awal hingga proses akhir.

\section{HASIL DAN PEMBAHASAN}

Penelitian ini bertujuan untuk menganalisa penerapan manajemen kredit pada Penyaluran Dana Program Kemitraan dan Bina Lingkungan (PKBL) PT. PELINDO II (Persero) Cabang Palembang dengan melakukan penelitian kepada 34 mitra binaan dan mengajukan 29 macam pertanyaan yang terdiri atas karakter, kondisi usaha, jaminan dan penyebab lainnya melalui kuesioner.

\section{Rekapitulasi Penerapan Manajemen Kredit}

\begin{tabular}{|c|l|c|c|c|}
\hline No. & \multicolumn{1}{|c|}{ Keterangan } & Jawaban & Frekuensi & Persen \\
\hline & Karakter & & & \\
\hline 1. & $\begin{array}{l}\text { Anggapan mitra binaan bahwa kredit PKBL } \\
\text { adalah hibah }\end{array}$ & $\begin{array}{l}\text { Tidak } \\
\text { setuju }\end{array}$ & 23 & 67,6 \\
\hline 2. & $\begin{array}{l}\text { Anggapan mitra binaan bahwa } \\
\text { pemerintah/BUMN tidak akan merugi jika } \\
\text { kredit tidak dikembalikan Sangat } \\
\text { setuju }\end{array}$ & 30 & 88,2 \\
\hline 3. & $\begin{array}{l}\text { Jika usaha mitra binaan berhasil lebih } \\
\text { mendahulukan petuju } \\
\text { dibandingkan membayar cicilan ke PT. }\end{array}$ & 24 & 70,6 \\
\end{tabular}


Ekonomica Sharia Volume 5 Nomor 1 Edisi Agustus 2019 | 35

\begin{tabular}{|c|c|c|c|c|}
\hline & PELINDO II (Persero) & & & \\
\hline 4. & $\begin{array}{l}\text { Kunjungan petugas PKBL tidak akan } \\
\text { memotivasi usaha mitra binaan }\end{array}$ & $\begin{array}{l}\text { Tidak } \\
\text { setuju }\end{array}$ & 17 & 50 \\
\hline 5. & $\begin{array}{l}\text { Anggapan mitra binaan bahwa kredit harus } \\
\text { dikembalikan jika jaminan yang diberikan } \\
\text { sebanding dengan kredit yang diterima }\end{array}$ & $\begin{array}{l}\text { Tidak } \\
\text { setuju }\end{array}$ & 28 & 82,4 \\
\hline 6. & $\begin{array}{l}\text { Anggapan mitra binaan bahwa sah-sah saja } \\
\text { menerima kredit dari BUMN lainnya }\end{array}$ & $\begin{array}{l}\text { Sangat } \\
\text { setuju }\end{array}$ & 30 & 88,2 \\
\hline 7. & $\begin{array}{l}\text { Kredit yang diterima tidak langsung digunakan } \\
\text { untuk pengembangan usaha }\end{array}$ & $\begin{array}{l}\text { Tidak } \\
\text { setuju }\end{array}$ & 21 & 61,8 \\
\hline 8. & $\begin{array}{l}\text { Motivasi mitra binaan dalam melunasi } \\
\text { pinjaman menurun jika menerima jumlah } \\
\text { pinjaman yang tidak sesuai }\end{array}$ & $\begin{array}{l}\text { Tidak } \\
\text { setuju }\end{array}$ & 27 & 79,4 \\
\hline & Kondisi usaha & & & \\
\hline 9. & $\begin{array}{l}\text { Jumlah pekerja, modal kerja dan omset usaha } \\
\text { tidak terjadi peningkatan }\end{array}$ & Setuju & 26 & 76,5 \\
\hline 10. & Pembelian bahan baku terjadi penurunan & Setuju & 26 & 76,5 \\
\hline 11. & Gagal panen & Setuju & 27 & 79,4 \\
\hline 12. & $\begin{array}{l}\text { Kesulitan tersedianya pasar/tempat memasarkan } \\
\text { produk mitra binaan }\end{array}$ & Setuju & 28 & 82,4 \\
\hline 13. & $\begin{array}{l}\text { Rendahnya minat konsumen untuk } \\
\text { mengkonsumsi produk mitra binaan }\end{array}$ & Setuju & 28 & 82,4 \\
\hline 14. & Upah pekerja meningkat & $\begin{array}{l}\text { Cukup } \\
\text { setuju }\end{array}$ & 27 & 79,4 \\
\hline 15. & Kesulitan mencari tenaga kerja & $\begin{array}{l}\text { Cukup } \\
\text { setuju }\end{array}$ & 26 & 76,5 \\
\hline \multirow[t]{2}{*}{16.} & Kejadian yang tidak diharapkan & Setuju & 27 & 79,4 \\
\hline & Jaminan & & & \\
\hline 17. & $\begin{array}{l}\text { Jaminan tidak harus sesuai dengan kredit yang } \\
\text { diterima }\end{array}$ & Setuju & 32 & 94,1 \\
\hline
\end{tabular}


36 | Meilin Veronica Penerapan Manajemen Kredit Pada Program.....

\begin{tabular}{|c|c|c|c|c|}
\hline 18. & $\begin{array}{l}\text { Anggapan mitra binaan bahwa pengajuan kredit } \\
\text { tidak perlu disertakan jaminan }\end{array}$ & $\begin{array}{l}\text { Tidak } \\
\text { setuju }\end{array}$ & 24 & 70,6 \\
\hline 19. & $\begin{array}{l}\text { Anggapan mitra binaan bahwa tanpa jaminan } \\
\text { pengajuan kredit akan tetap diproses }\end{array}$ & $\begin{array}{l}\text { Tidak } \\
\text { setuju }\end{array}$ & 28 & 82,4 \\
\hline 20. & $\begin{array}{l}\text { Anggapan mitra binaan bahwa prospek } \\
\text { usahanya tidak cukup sebagai jaminan tetapi } \\
\text { dengan harta tetap }\end{array}$ & Setuju & 29 & 85,3 \\
\hline \multirow[t]{2}{*}{21.} & $\begin{array}{l}\text { Jaminan merupakan alat yang tidak bisa } \\
\text { dipertimbangkan untuk melunasi tunggakan }\end{array}$ & Setuju & 31 & 91,2 \\
\hline & Penyebab lainnya & & & \\
\hline 22. & $\begin{array}{l}\text { Mitra binaan menerima jumlah bantuan kredit } \\
\text { secara tidak utuh }\end{array}$ & $\begin{array}{l}\text { Tidak } \\
\text { setuju }\end{array}$ & 21 & 61,8 \\
\hline 23. & $\begin{array}{l}\text { Terjadinya bencana alam tidak dapat menjadi } \\
\text { alasan untuk tidak melunasi tunggakan }\end{array}$ & Setuju & 22 & 64,7 \\
\hline 24. & $\begin{array}{l}\text { Terjadinya perubahan selera masyarakat } \\
\text { terhadap produk mitra binaan }\end{array}$ & Setuju & 33 & 97,1 \\
\hline 25. & Pemilik usaha meninggal dunia & $\begin{array}{l}\text { Cukup } \\
\text { setuju }\end{array}$ & 22 & 64,7 \\
\hline 26. & $\begin{array}{l}\text { Anggapan mitra binaan bahwa yang harus } \\
\text { dilunasi hanya pokok pinjamannya saja } \\
\text { sedangkan bunga tidak harus dibayar. }\end{array}$ & $\begin{array}{l}\text { Tidak } \\
\text { setuju }\end{array}$ & 24 & 70,6 \\
\hline 27. & Mitra binaan pindah lokasi tempat usaha & $\begin{array}{l}\text { Cukup } \\
\text { setuju }\end{array}$ & 23 & 67,6 \\
\hline 28. & $\begin{array}{l}\text { Mitra binaan menggunakan kredit yang } \\
\text { diterimanya tidak sesuai dengan yang tercantum } \\
\text { pada proposal }\end{array}$ & $\begin{array}{l}\text { Tidak } \\
\text { setuju }\end{array}$ & 20 & 58,8 \\
\hline 29. & $\begin{array}{l}\text { Calon mitra binaan menjanjikan sesuatu kepada } \\
\text { petugas PKBL }\end{array}$ & $\begin{array}{l}\text { Tidak } \\
\text { setuju }\end{array}$ & 29 & 85,3 \\
\hline
\end{tabular}




\section{KARAKTER}

Berdasarkan 8 (delapan) pertanyaan dalam kuisioner tentang Karakter di atas dapat dianalisa jawaban dari mitra binaan tentang penyebab macetnya tunggakan adalah sebagai berikut :

1) Mitra binaan tidak setuju jika kredit PKBL ini adalah hibah/bantuan Cuma-Cuma dari pemerintah/BUMN.

Anggapan tersebut timbul antara lain dikarenakan pihak mitra binaan diwajibkan untuk membayar pinjaman tersebut tiap bulannya. Pihak mitra binaan juga diberikan data-data secara rinci tentang berapa bunga yang dibebankan dan berapa angsuran yang wajib dibayarkan tiap bulannya.

Untuk itu, kepada petugas PKBL agar selain memberikan draft perjanjian kerjasama juga sebaiknya memberikan penjelasan sehingga tidak terjadi salah pengertian dari mitra binaannya.

2) Mitra binaan sangat setuju jika pinjaman kredit PKBL ini tidak dikembalikan maka pemerintah tidak akan rugi.

Anggapan tersebut timbul antara lain dikarenakan mitra binaan merasa pinjaman yang mereka terima jumlahnya kecil dibandingkan jumlah keseluruhan pinjaman yang macet.

Untuk itu, kepada PKBL PT. PELINDO II Cabang Palembang agar :

a. Sebaiknya menjelaskan kepada mitra binaan supaya tidak terjadi salah pengertian tentang Program PKBL

b. Sebaiknya membangkitkan kesadaran kepada mitra binaan bahwa pinjaman PKBL harus dibayar sampai lunas.

3) Mitra binaan setuju jika usahanya berhasil, lebih memilih perluasan usaha dibandingkan melunasi cicilan kredit.Mitra binaan lebih suka memperluas usahanya jika usahanya berhasil dibandingkan melunasi angsuran pinjaman, karena angsuran pinjaman bisa menunggak dan apabila menunggak maka tidak ada sanksi yang tegas dari PKBL PT. PELINDO II Cabang Palembang kepada mitra binaan tersebut meskipun telah menunggak selama beberapa kali (beberapa bulan) angsuran atau menunggak dalam jangka waktu yang lebih lama lagi.

Untuk itu, kepada PKBL PT. PELINDO II Cabang Palembang agar : 
38 | Meilin Veronica Penerapan Manajemen Kredit Pada Program.....

a. Lebih ditingkatkan lagi dalam mengirimkan surat pemberitahuan apabila mitra binaan telat/belum membayar pinjaman dari tanggal yang ditentukan.

b. Sebaiknya memberikan sanksi yang tegas kepada mitra binaan yang tidak membayar pinjaman kredit.

4) Mitra binaan tidak setuju jika kunjungan petugas PKBL yang memonitor setelah pinjaman diterima tidak dapat memotivasi usaha mitra binaan.

Menurut mitra binaan, mereka merasa terbantu dengan adanya kunjungan petugas lapangan PKBL yang memonitor kemajuan usahanya, petugas PKBL dapat memotivasi dan memberikan saran-saran guna perbaikan kinerja usaha mitra binaan agar lebih berhasil.

Untuk itu, kepada petugas PKBL agar terus mempertahankan kegiatan memonitor/melakukan kunjungan ke mitra binaan sehingga bisa mengurangi tunggakan pinjaman kredit tersebut.

5) Mitra binaan tidak setuju jika pinjaman harus dilunasi jika agunan yang diberikan nilainya sebanding dengan pinjaman yang diterima karena mitra binaan beranggapan bahwa pinjaman tetap harus dilunasi walaupun pinjaman yang diterima tidak sebanding dengan agunan yang diberikan.Untuk itu, kepada PKBL PT. PELINDO II Cabang Palembang agar sebaiknya mempunyai petugas yang mempunyai keahlian dalam menilai asset tetap dan ditugaskan khusus untuk menilai (appraisal) harta tetap yang akan dijaminkan oleh mitra binaan supaya dapat diketahui berapa nilai dari agunan yang diserahkan yang dapat diterima oleh kedua belah pihak.

6) Mitra binaan sangat setuju jika menerima pinjaman kredit selain dari PT. PELINDO II Cabang Palembang juga menerima dari BUMN lain.Anggapan tersebut karena menurut persepsi mitra binaan :

a. Asalkan dana pinjaman tersebut dikelola secara lebih baik dan bertanggungjawab maka tidak apa-apa dan sah-sah saja jika menerima pinjaman kredit dari lebih satu BUMN.

b. Selain itu jika menerima pinjaman kredit lebih dari satu BUMN bukanlah perbuatan yang bertentangan dengan hukum. 
c. Asalkan jaminan dan usaha mitra binaan yang diserahkan ke kedua BUMN tersebut bukanlah sesuatu yang sama.

d. Mitra binaan berpendapat jika memperoleh dana pinjaman yang lebih besar maka mereka akan lebih leluasa dalam membelanjakannya untuk memperluas usaha mereka.

Terhadap kondisi di atas, maka kepada PKBL PT. PELINDO II Cabang Palembang agar sebaiknya berkoordinasi dengan PKBL BUMN lain untuk saling bertukar informasi dan data mengenai nama/jenis usaha dan jaminan yang diserahkan untuk memperoleh pinjaman supaya tidak terjadi nama/jenis usaha dan jaminan yang sama akan tetapi diserahkan ke PKBL BUMN yang berbeda.

7) Mitra binaan tidak setuju jika dana pinjaman yang diterima tidak langsung digunakan untuk pengembangan usaha (sengaja ditunda-tunda) karena mitra binaan beranggapan bahwa dana pinjaman itu harus digunakan untuk pengembangan usaha agar usahanya maju dan berkembang.

Untuk itu, kepada petugas PKBL agar :

a. Terus mempertahankan kegiatan monitoring mitra binaan dengan menugaskan petugas survey untuk mengunjungi lokasi dan memeriksa fisik barang, untuk membuktikan apakah dana yang telah diterima oleh mitra binaan memang benar telah dipergunakan sesuai dengan proposal yang diajukan.

b. Sebaiknya diwajibkan kepada mitra binaan agar menyerahkan dokumen asli bukti pembelian yang berupa faktur, nota atau kuitansi pembelian barangbarang dan dikirimkan ke kantor Program PKBL.

8) Mitra binaan tidak setuju jika motivasi mitra binaan dalam melunasi pinjamannya akan menurun jika menerima jumlah pinjaman yang tidak sesuai dengan yang diharapkan karena mitra binaan beranggapan bahwa meskipun jumlah yang diterima lebih kecil namun tetap harus dilunasi tunggakannya karena itu merupakan kewajiban sebagaimana tercantum dalam perjanjian pinjaman.

Untuk itu, kepada petugas PKBL agar mempertahankan dalam memberikan penjelasan bahwa berapapun pinjaman yang diberikan, mitra binaan tetap harus membayar pinjaman kredit yang diberikan kepadanya. 
$40 \mid$

Meilin Veronica Penerapan Manajemen Kredit Pada Program.....

\section{KONDISI USAHA}

Berdasarkan 8 (delapan) pertanyaan dalam kuisioner tentang kondisi usaha di atas dapat dianalisa jawaban dari mitra binaan tentang penyebab macetnya tunggakan adalah sebagai berikut :

1) Mitra binaan yang disampel setuju jika jumlah pekerja, modal kerja, omzet usaha tidak terjadi peningkatan menyebabkan kemampuan membayar pinjaman menurun. Untuk itu, kepada petugas PKBL agar sebaiknya memberikan pendidikan kepada mitra binaan bagaimana cara mengelola pekerja dan modal usaha.

2) Mitra binaan yang disampel setuju jika pembelian bahan baku terjadi penurunan menyebabkan penurunan pendapatan sehingga kemampuan untuk membayar pinjaman menurun. Untuk itu, kepada petugas PKBL agar sebaiknya memberikan pendidikan tentang alternatif usaha lain yang bisa dikembangkan mitra binaan tersebut.

3) Mitra binaan yang disampel setuju jika panen yang diharapkan bagus ternyata gagal menyebabkan penurunan pendapatan sehingga kemampuan untuk membayar pinjaman menurun. Untuk itu, kepada petugas PKBL agar sebaiknya survey langsung ketempatnya dan jika benar bisa diberikan perpanjangan waktu.

4) Mitra binaan yang disampel setuju jika terjadi kesulitan tempat memasarkan dari produk-produk yang dihasilkannya menyebabkan mitra binaan tidak dapat memperluas usahanya sehingga pendapatan yang dihasilkan tidak dapat berkembang dan berpengaruh pada kemampuan membayar pinjaman.

Untuk itu, kepada Program PKBL PT. PELINDO II Cabang Palembang agar sebaiknya mengajak mitra binaan tersebut untuk mengikuti pameran UKM hal itu bertujuan sebagai ajang promosi produk sekalian mencari pangsa pasar dan tempat pemasaran produk yang baru.

5) Mitra binaan yang disampel setuju jika rendahnya minat masyarakat/konsumen untuk mengkonsumsi produk-produk yang dihasilkan oleh mitra binaan menyebabkan penurunan pendapatan sehingga kemampuan untuk membayar pinjaman menurun. Untuk itu, kepada PKBL PT. PELINDO II Cabang Palembang agar sebaiknya dilakukan pembinaan tentang inovasi produk-produk yang mengikuti selera konsumen dan perkembangan trend. 
Ekonomica Sharia Volume 5 Nomor 1 Edisi Agustus $2019 \mid 41$

6) Mitra binaan yang disampel setuju jika upah pekerja meningkat dan tidak sesuai lagi dengan kondisi sekarang menyebabkan kemampuan membayar pinjaman menurun. Untuk itu, kepada PKBL PT. PELINDO II Cabang Palembang agar sebaiknya dilakukan pembinaan tentang mengelola usaha dan pekerja sehingga dapat mengeluarkan biaya yang seefisien mungkin.

7) Mitra binaan yang disampel setuju jika kesulitan dalam mencari tenaga kerja yang keahliannya cocok dengan kebutuhan usaha mitra binaan berpengaruh terhadap hasil produksi. Hal ini berdampak pada jangka waktu dan biaya yang dikeluarkan.

Untuk itu, kepada PKBL PT. PELINDO II Cabang Palembang agar sebaiknya dilakukan pembinaan kepada mitra binaan mengenai cara melatih pekerja, cara menggunakan fasilitas yang ada sehingga menjadi ahli.

8) Mitra binaan yang disampel setuju jika terjadi kejadian yang tidak diharapkan berdampak pada usaha mitra binaan.

Terhadap kondisi di atas maka yang dapat dilakukan oleh PKBL PT. PELINDO II Cabang Palembang:

(1) Sebaiknya menyarankan kepada mitra binaan untuk mengasuransikan usahanya untuk menghindari kejadian yang tidak diinginkan, misalnya kebakaran atau kehilangan.

(2) Jika usaha mitra binaan mengalami kejadian tersebut dan ternyata usahanya tidak diasuransikan akibatnya usaha mitra binaan habis sehingga tidak bisa melunasi tunggakannya dan kejadian tersebut bukan kesengajaan atau hasil rekayasa mitra binaan maka sebaiknya PKBL mengusulkan ke PKBL PT. PELINDO Kantor Pusat untuk menghapus bukukan atau write-off dari segala hutangnya.

\section{JAMINAN}

Berdasarkan 5 (lima) pertanyaan dalam kuisioner tentang jaminan di atas, maka dapat dianalisa jawaban dari mitra binaan tentang penyebab macetnya tunggakan adalah sebagai berikut :

1) Mitra binaan yang disampel setuju jika jaminan yang diserahkan nilainya tidak harus sesuai dengan kredit yang diterima karena mitra binaan beranggapan bahwa 
jaminan yang diserahkan bisa lebih kecil atau lebih besar dengan kredit yang diterima. Untuk itu, kepada PKBL PT.PELINDO II Cabang Palembang agar mempertahankan dalam memeriksa dengan teliti jaminan yang diserahkan oleh mitra binaan. Apakah jaminan tersebut merupakan milik sendiri atau milik orang lain.

2) Mitra binaan yang disampel tidak setuju jika pengajuan kredit tidak perlu disertakan jaminan. Ini berarti pengajuan proposal pinjaman mesti disertakan jaminan karena mitra binaan beranggapan bahwa tanpa jaminan maka proposal pinjaman tidak akan disetujui.

Untuk itu, kepada PKBL PT. PELINDO II Cabang Palembang agar syarat pengajuan kredit tetap dipertahankan yaitu dengan memeriksa proposal yang masuk, apakah ada jaminannya atau tidak.

3) Mitra binaan yang disampel tidak setuju jika tanpa diberikan jaminanpun proposal kredit yang diajukan akan tetap diproses karena mitra binaan beranggapan bahwa jika proposal pinjaman yang diajukan tanpa disertai dengan jaminan berupa harta tetap maka proposal pinjaman yang diajukan tidak akan diproses oleh PKBL PT. PELINDO II Cabang Palembang.

Untuk itu, kepada PKBL PT. PELINDO II Cabang Palembang agar syarat proposal pinjaman tetap dipertahankan yaitu dengan memeriksa dengan teliti jaminan yang disertakan oleh mitra binaan itu.

4) Mitra binaan yang disampel setuju bahwa prospek usahanya saja tidak cukup sebagai jaminan tetapi harus disertai aktiva tetap sebagai jaminan karena mitra binaan beranggapan bahwa selain prospek usaha, jaminan berupa harta tetap juga harus disertakan dalam pengajuan proposal.

Untuk itu, kepada PKBL PT. PELINDO II Cabang Palembang agar tetap dipertahankan dalam memeriksa prospek usaha dan harta tetap mitra binaan guna mengetahui kemampuan mitra binaan dalam membayar pinjaman.

5) Mitra binaan yang disampel setuju jika jaminan merupakan suatu alat yang tidak bisa dipertimbangkan untuk melunasi tunggakan kreditnya karena menurut mitra binaan tanpa ada jaminanpun mereka akan tetap berusaha untuk melunasi tunggakannya. Selain itu jaminan yang berupa harta tetap bukanlah satu-satunya 
syarat yang harus dipertimbangkan dalam permohonan pengajuan kredit, masih terdapat beberapa syarat lagi. Ada 2 (dua) syarat utama dalam pengajuan kredit yaitu Jaminan dan Kelangsungan Usaha.

Untuk itu, kepada PKBL PT. PELINDO II Cabang Palembang agar tetap dipertahankan dalam memeriksa jaminan tetapi juga prospek atau kelangsungan usaha mitra binaan.

\section{PENYEBAB LAINNYA}

Berdasarkan 8 (delapan) pertanyaan dalam kuisioner tentang penyebab lainnya di atas, maka dapat dianalisa jawaban dari mitra binaan tentang penyebab macetnya tunggakan adalah sebagai berikut :

1) Mitra binaan yang disampel tidak setuju jika menerima jumlah bantuan kredit secara tidak utuh (dipotong) karena mitra binaan beranggapan bahwa pinjaman kredit yang diterimanya adalah utuh tanpa dipotong. Untuk itu, kepada PKBL PT. PELINDO II Cabang Palembangagar mempertahankan dalam memberikan pinjaman secara utuh sehingga dana tersebut dapat dipergunakan untuk perluasan usahanya.

2) Mitra binaan yang disampel setuju jika terjadinya bencana alam di lokasi usaha mitra binaan tidak dapat menjadi alasan untuk tidak melunasi tunggakan karena menurut mitra binaan pinjaman harus dilunasi tanpa alasan apapun. Untuk itu, kepada PKBL PT. PELINDO II Cabang Palembang agar :

a) Sebaiknya melakukan survey ke lokasi mitra binaan untuk mendapatkan informasi dan mengumpulkan fakta-fakta serta mengetahui secara pasti apakah tutupnya usaha mitra binaan tersebut benar-benar disebabkan oleh bencana alam atau kejadian yang tidak dapat dihindarkan lainnya, dan bukan disengaja atau hasil rekayasa oleh mitra binaan.

b) Jika memang sudah diketahui penyebabnya secara pasti memang bukan suatu kesengajaan, maka PKBL PT. PELINDO II Cabang Palembang sebaiknya dapat mengusulkan usaha mitra binaan tersebut ke PKBL PT. PELINDO Kantor Pusat untuk di hapuskan atau write-offdari tunggakannya. 
44 | Meilin Veronica Penerapan Manajemen Kredit Pada Program.....

3) Mitra binaan yang disampel setuju jika terjadinya perubahan selera/minat masyarakat terhadap produk-produk yang dihasilkan oleh mitra binaan berpengaruh terhadap pelunasan tunggakan kreditnya karena menurut mitra binaan, perubahan selera/minat masyarakat mempengaruhi pendapatan usaha yang diterima oleh mitra binaan. Untuk itu, kepada PKBL PT. PELINDO II Cabang Palembang agar sebaiknya memberikan pembinaan mengenai inovasi produk sehingga dapat mengikuti selera masyarakat atau perkembangan trend.

4) Mitra binaan yang disampel berpendapat jika pengelola usaha atau suami dan istri dari pengelola usaha meninggal dunia "cukup berpengaruh" terhadap pelunasan tunggakan kreditnya karena mitra binaan beranggapan jika pemilik usaha meninggal dunia maka tidak ada orang yang akan mengurus usaha tersebut dan usaha tersebut akan terbengkalai. Meninggalnya pemilik atau suami dan istri dari pemilik jelas akan mempengaruhi kemampuan usaha mitra binaan tersebut untuk melunasi tunggakannya.

Untuk itu, kepada PKBL PT. PELINDO II Cabang Palembang agar :

a. Jika usaha mitra binaan tidak ada ahli waris yang mengurus atau melanjutkan usahanya. Jika tidak ada seseorang yang melanjutkan untuk mengurus usaha tersebut sehingga usaha tersebut terancam terbengkalai, maka yang dapat dilakukan oleh PKBL PT. PELINDO II Cabang Palembangsebaiknya mengusulkan kepada PKBL PT. PELINDO Kantor Pusat supaya sisa hutang tunggakan mitra binaan tersebut untuk dihapuskan atau write-off.

b. Jika usaha mitra binaan ada ahli waris yang melanjutkan usahanya.

Jika ada seseorang atau ahli waris yang melanjutkan untuk mengelola usaha tersebut sehingga usaha tesebut tidak terbengkalai dan orang tersebut bersedia membuat perjanjian secara tertulis untuk mengambil alih usaha dan sisa tunggakan, maka yang dapat dilakukan oleh PKBL PT. PELINDO II Cabang Palembang adalah agar sebaiknya tunggakan usaha tersebut dikondisikan kembali (reconditioning) atau di jadwal kembali pelunasannya (rescheduling).

5) Mitra binaan yang disampel tidak setuju jika pinjaman kredit tersebut yang harus dilunasi hanya pokok pinjamannya saja, sedangkan bunga/ imbal hasil tidak harus dibayar karena menurut mitra binaan imbal hasil atau bunga harus dibayar karena 
Ekonomica Sharia Volume 5 Nomor 1 Edisi Agustus $2019 \mid 45$

tercantum dalam perjanjian kerjasama antara mitra binaan dengan PT. PELINDO II (Persero) Cabang Palembang.Untuk itu, kepada PKBL PT. PELINDO II Cabang Palembang agar tetap dipertahankan dalam memberikan penjelasan kepada mitra binaan yang baru bahwa bunga juga harus dibayar.

6) Mitra binaan yang disampel berpendapat jika mitra binaan pindah lokasi tempat usahanya maka hal itu "cukup berpengaruh" terhadap pelunasan tunggakan kreditnya karena mitra binaan boleh saja pindah atau memindahkan lokasi usahanya asal kepindahan tersebut harus dengan alasan yang jelas, tepat dan dapat dipertanggung jawabkan. Jangan sampai kepindahan lokasi usaha tersebut hanya rekayasa dari pemilik untuk menghindari pembayaran utang atau melarikan diri dari hutangnya. Kepindahan lokasi tersebut sebelumnya harus dilaporkan ke pihak PKBL PT. PELINDO II Cabang Palembang agar memudahkan pihak PKBL yang akan melakukan survey dan monitoring.

Alasan mitra binaan pindah bisa dikarenakan :

(1) Lokasi lama dianggap tidak aman (kecurian, dll.)

(2) Terjadi musibah di lokasi lama

(3) Sengaja melarikan diri dari hutang

Untuk itu, kepada PKBL PT. PELINDO II Cabang Palembang agar sebaiknya melakukan monitoring rutin ke lokasi mitra binaan untuk mengetahui ada tidaknya mitra binaan yang memindahkan lokasi usahanya.

7) Mitra binaan yang disampel tidak setuju jika menyalahgunakan pinjaman kredit yang diterimanya karena mitra binaan beranggapan bahwa penyalahgunaan dana pinjaman tersebut berdampak terhadap perkembangan usaha dalam hal penurunan pendapatan karena dana yang seharusnya dipakai untuk kepentingan usaha malah disalahgunakan.

Untuk itu, kepada PKBL PT. PELINDO II Cabang Palembang agar sebaiknya memeriksa apakah mitra binaan menggunakan dana pinjaman itu sebagaimana mestinya dengan survey langsung ketempat usaha dan meminta bukti-bukti pembelian.

8) Mitra binaan yang disampel tidak setuju jika menjanjikan imbalan kepada Petugas PKBL supaya pinjaman yang di ajukannya dapat disetujui karena mitra 
46 | Meilin Veronica Penerapan Manajemen Kredit Pada Program.....

binaan beranggapan bahwa mereka tidak pernah menjanjikan imbalan kepada petugas PKBL. Mereka percaya bahwa proses persetujuan dana pinjaman ini dilakukan secara profesional.

Untuk itu, kepada petugas PKBL agar tetap dipertahankan bekerja secara profesional dalam menjalankan tugasnya. Hal ini untuk mengurangi tunggakan yang akan terjadi dimasa yang akan datang.

\section{KESIMPULAN DAN SARAN}

\section{Kesimpulan}

1. Berdasarkan hasil analisa penerapan manajemen kredit pada program kemitraan dan bina lingkungan melalui Karakter, Kondisi Usaha, Jaminan, dan Penyebab lainnya maka dapat disimpulkan bahwa Karakter dari mitra binaan yang beranggapan bahwa PT. PELINDO II tidak akan merugi meskipun kredit yang diterima tidak dikembalikan. Dilihat dari sampel kuisoner dimana 30 mitra binaan $(88,2 \%)$ sangat setuju jika pinjaman kredit PKBL ini tidak dikembalikan maka PT. PELINDO II tidak akan rugi sehingga sangat berperan dalam menimbulkan besarnya jumlah tunggakan.

2. Berdasarkan hasil penelitian terhadap peraturan Menteri Negara BUMN No. PER05/MBU/2007 Tentang Program Kemitraan dan Bina Lingkungan pada Pasal 4 dimana banyak Mitra Binaan yang tidak menjalankan kewajibannya kepada PT. PELINDO II yang mengakibatkan besarnya jumlah tunggakan yang terdapat pada PT. PELINDO II, adapun kewajiban Mitra Binaan sebagai berikut:

a. Melaksanakan kegiatan usaha sesuai dengan rencana yang telah disetujui oleh BUMN Pembinaan atau BUMN Penyalur atau Lembaga Penyalur;

b. Membayar kembali pinjaman secara tepat waktu sesuai dengan perjanjian yang telah disepakati;

c. Menyampaikan laporan perkembangan usaha secara periodik kepada BUMN Pembina. 


\section{Saran}

1. Agar permasalahan kredit macet yang disebabkan oleh faktor karakter, kondisi usaha, jaminan dan penyebab lainnya tidak terulang lagi pada periode penyaluran selanjutnya maka kepada Program PKBL PT. PELINDO II Cabang Palembang agar :

a. Sebaiknya Menghilangkan miskomunikasi dengan mitra binaan bahwa pinjaman PKBL harus dibayar sampai lunas, sebaiknya memberikan tenggat waktu jika masih dilanggar maka sanksi yang tegas bagi yang menunggak lebih dari 2 (dua) bulan

b. Melakukan kerjasama kepada pihak asuransi sebagai penjamin apabila terdapat Mitra Binaan yang mengalamai musibah atas usahanya sehingga menyebabkan kredit macet dan tidak mampu untuk membayar kredit tersebut.

c. Berkoordinasi dengan PKBL BUMN lain untuk saling bertukar informasi dan data

d. Melakukan survey segera setelah mitra binaan menerima dana pinjaman untuk mengetahui apakah dana digunakan sesuai proposal, mewajibkan mitra binaan untuk menyerahkan dokumen asli bukti pembelian yang berupa faktur, nota atau kuitansi pembelian barang-barang dan dikirimkan ke kantor Program PKBL.

e. Mengefektifkan kunjungan ke lokasi mitra binaan untuk melakukan monitoring sekaligus melakukan pembinaan tentang cara pengembangan usaha, agar usaha mitra binaan bisa lebih maju, dan bila memungkinkan dapat mengajak mitra binaan tersebut untuk mengikuti pameran UKM untuk memasarkan produk-produknya.

f. Mengetatkan persayaratan jaminan berupa harta tetap, meneliti kepemilikan dari harta tetap tersebut, serta menyarankan kepada mitra agar mengasuransikan usahanya untuk menghindari kejadian yang tidak diinginkan, mempunyai petugas yang mempunyai keahlian dalam menilai asset tetap dan ditugaskan khusus untuk menilai (appraisal) harta tetap yang akan dijaminkan sehingga dapat diketahui berapa nilai dari agunan yang diserahkan yang dapat diterima oleh kedua belah pihak. 
g. Melakukan survey ke lokasi mitra binaan untuk membuktikan tutupnya usaha mitra binaan tersebut benar-benar disebabkan oleh bencana alam, dan jika mitra binaan meninggal dunia maka jika usaha mitra binaan tidak ada ahli waris maka akan diusulkan kepada PKBL PT. PELINDO Kantor Pusat supaya sisa hutangnya untuk dihapuskan atau write-off.Namun jika usaha mitra binaan ada ahli waris maka sisa tunggakan usaha tersebut di reconditioningatau rescheduling). Jika pindah lokasi usaha maka agar melakukan monitoring rutin ke lokasi mitra binaan untuk mengetahui ada tidaknya mitra binaan yang memindahkan lokasi usahanya.

2. Berdasarkan hasil analisa kelayakan pemberian pinjaman, maka kepada PKBL PT. PELINDO II Cabang Palembang agar meneliti lebih detail tentang kepemilikan harta tetap, dan melakukan konfirmasi kepada pemilik jaminan harta tetap tersebut.Saran yang dapat diberikan untuk perbaikan kinerja penyaluran kredit program kemitraan dengan usaha kecil di masa depan adalah :

1) Seleksi calon mitra binaan harus dilakukan dengan benar dan transparan, terutama pada kegiatan pemeriksaan kelengkapan proposal, dan kegiatan pemeriksaan (survey) secara langsung ke lokasi usaha mitra binaan.

2) Kegiatan monitoring hendaknya dilakukan secara lebih sering (lebih intensif) ke lokasi usaha mitra binaan agar jika terjadi permasalahan lebih cepat diketahui.

3) Jika terdapat pinjaman mitra binaan yang macet, usaha yang dapat dilakukan untuk pengumpulan piutang macet tersebut adalah dengan mengefektifkan fungsi penagihan dengan cara:

(1) Menggunakan pendekatan secara lebih persuasif, dengan lebih sering melakukan penagihan ke mitra binaan.

(2) Melakukan kunjungan dan penagihan secara langsung kepada mitra binaan.

(3) Melakukan penagihan secara langsung dengan cara bekerjasama dengan pihak ketiga. 


\section{DAFTAR PUSTAKA}

Keputusan Menteri Badan Usaha Milik Negara Nomor KEP-236/MBU/2003Tentang Program Kemitraan Badan Usaha Milik Negara dengan Usaha Kecil dan Program Bina Lingkungan.

Kwartono Adi, 2009, Kiat Sukses Berburu Modal UMKM, Jakarta: Raih Asa Sukses.

Murti Sumarni dan Salamah Wahyuni, 2006, Metodologi Penelitan Bisnis, Edisi I, Yogyakarta: ANDI.

Peraturan Menteri Badan Usaha Milik Negara Nomor PER-02/MBU/7/2017Tentang Program Kemitraan dan Program Bina Lingkungan.

Peraturan Menteri Badan Usaha Milik Negara Nomor per-05/mbu/2007 Program Kemitraan Badan Usaha Milik Negara Dengan Usaha Kecil dan Program Bina Lingkungan. Peraturan Pemerintah No 44 Tahun 1997 Tentang Kemitraan

Robert Tampubolon, 2004, Manajemen Resiko, Jakarta: Gramedia.

Ross, A. Stephen, 2008, Modern Financial Management, Eight Edition, New York: Mc.Graw Hill.

Spencer, 1977 dalam Badan Agribisnis Departemen Pertanian, 1998

Undang-Undang Nomor 20 Tahun 2008 Tentang Usaha Mikro, Kecil dan Menengah Pasal 1 ayat 13

Undang-undang RI Nomor 19 Tahun 2003 tentang Badan Usaha Milik Negara

Weston, J. Fred, dan Eugene F Brigham.(2008). Dasar-dasar Manajemen Keuangan (2th ed).Jakarta :Erlangga

Yusuf Wibisono. Membedah Konsep dan Aplikasi CSR. Fascho Publishing. Gresik. 2007. hal. 103. 
50 | Meilin Veronica Penerapan Manajemen Kredit Pada Program..... 